\title{
Preliminary Analysis on the River Danube Water Quality by Using Different Kinds of Methods
}

\author{
Mihaela Timofti*, Catalina Iticescu, Maxim Arseni, Madalina Calmuc, Valentina-Andreea \\ Calmuc, Lucian Puiu Georgescu \\ ECEE of Sciences and Environment Faculty, Dunarea de Jos University, Domneasca Street no. 111, Galati, \\ Romania.
}

* Corresponding author. Tel.: +40765211135; email: timoftimihaela@gmail.com,mtimofti@ugal.ro Manuscript submitted August 4, 2018; accepted December 3, 2018.

doi: 10.17706/ijbbb.2019.9.1.65-72

\begin{abstract}
In Romania, the surface waters monitoring is carried out for most of the water quality indicators, according to the specific European Directives, generally once a month. The most important surface water in Romania is the Danube River, which is the second largest river in Europe. In this study, approximatively 30 chemical and physico-chemical indicators were monitored weekly for over a two-month period. The parameters were determined using different types of methods (volumetric, electrochemical, spectrophotometry, AAS).

The results obtained were subjected to a preliminary statistical study which included: t-Test, Pearson correlation and BoxPlot representation. Other statistical methods among which ANOVA, PCA, FA etc. will be applied later. Preliminary statistical methods have led to some expected results, but also to some surprising results. For some of the indicators (e.g., nutrients), it would be better if the monitoring were performed weekly rather than monthly as it is performed in the moment. This would help authorities intervene in time to identify the pollution event and, why not, the polluter.
\end{abstract}

Key words: Surface water monitoring, statistical analysis.

\section{Introduction}

After Volga River, the Danube is the second longest river in Europe $(2858 \mathrm{~km})$. It springs in the Black Forest Mountains (Germany) flowing to the southeast forming the Danube Delta before it reaches the Black Sea. The Danube is an international river road which flows through 10 countries (Germany, Austria, Slovakia, Hungary, Croatia, Serbia, Romania, Bulgaria, Republic of Moldova, Ukraine), has tributaries in seven other countries and passes through four state capitals: Vienna, Bratislava, Budapest and Belgrade [1]. The Danube Delta entered UNESCO World Heritage in 1991 and its site has been protected as a wetland of international importance since the Ramsar Convention on Wetlands organized on 21 May 1991 [2].

The lower course of the Danube represents about 30\% of its length, this river passing through Romania and running over 1,075 $\mathrm{km}$ between Baziaş and Sulina [1].

Taking into account the importance of this river, the DANUBIUS-RI strategic project, coordinated by Romania, which is on the list of major pan-European research infrastructures projects, is being implemented at European level. The project will ensure the socio-economic development of the respective regions by creating knowledge-based economies, their environmental protection and the preservation of biodiversity, as well as the sustainable use of their natural resources. 
Since the Danube is the source of water supply of numerous human communities existing along its course, having relevant information about the quality of its water is extremely important. According to the EU directives, the water of the Danube River is in the GOOD water quality class, class 2, from an ecological point of view this classification resulting from the monthly monitoring of the Danube water by competent authorities and by researchers concerned with the water quality of the Danube and of its tributaries. The sample area for this study is located near Galati City, this area being the largest hydrographic basin in Romania. this is also the point of confluence of the Danube River with two of the largest rivers in Romania, namely the Siret and Prut [3]. This area is highly industrialized, the anthropogenic impact being very important [4].

\section{Materials and Methods}

\subsection{Sampling Points}

Galati is located about $80 \mathrm{~km}$ away from the Danube Delta, the Danube River and its two important tributaries: the Siret and Prut flowing through this city. Under the circumstances, it was considered necessary to monitor the water quality indicators envisaged in 5 relevant sampling points, the distance between the first and the last sampling points being of approximately $25 \mathrm{kms}$. The sampling points are represented by a yellow square in Fig. 1. The two confluences were captured between the 5 sampling points, and their coding was made according to the locations where the samples were taken, on the direction of the Danube flowing to the Danube Delta, as follows: PD - Danube (first point), DS - Danube after the confluence with River Siret, DL - The Danube at the Libertatea ship, CT - Cotul pisicii and DP - Danube after the confluence with the Prut.

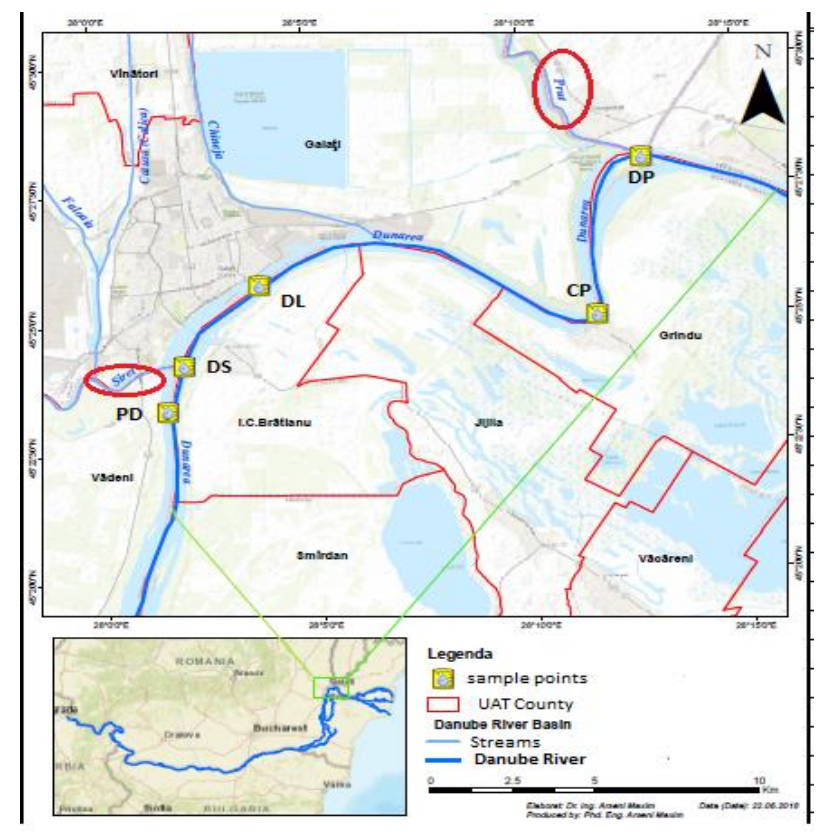

Fig. 1. The sampling points.

\subsection{Water Quality Indicators Tracked}

Considering the constant need to protect the freshwaters, especially the surface waters used for obtaining drinking water, this paper presents the results of the preliminary statistical analysis included in a short-term study. In order to establish which are the most important quality indicators with values higher than the MCA affecting both the quality of aquatic life and the possibility of making drinking water in 
drinking stations, the study initially assumed a weekly monitoring for 2 months between June and July 2018 . Thus, 27 chemical and physico-chemical quality water indicators were monitored using standardized methods of analysis, as well as conventional laboratory methods or methods analogous to standardized methods [5]-[24]. The water quality indicators pursued were: $\mathrm{pH}$, conductivity (C), Total Dissolved Solids (TDS), Dissolved Oxygen (DO), Oxygen Saturation (DO_Sat), Turbidity, Total Suspended Matter (TSM), M_Alkalinity, anion content of HCO3, DT, D_t, D_p, $\Sigma \mathrm{Ca}+\mathrm{Mg}$, Ca, Mg, chemical oxygen consumption (COD), Carbon Organic Total (TOC), N_total, N_NH4, N_NO2, P_total, Cl, SO4, Fe_total, Zn, Pb, Ni.

The samples were taken from a point in the middle of the river where the water was about $3 \mathrm{~m}$ deep, and the sampling, the manipulation and the preservation of all the samples was made according to the standards in force [25], [26].

\subsection{Methods of Analysis of Water Quality Indicators}

The methods of analysis used to determine the parameters of the water quality indicators pursued were chemical, instrumental and mathematical computation. Thus, these parameters were analyzed by using:

- Electrochemical methods: pH, C, TDS, DO, DO_Sat [5]-[7];

- Optical methods: Turbidity [8];

- Gravimetric method: TSM [9];

- Volumetric and mathematical computation methods: M_Alkalinity, HCO3, DT, D_t, D_p, $\Sigma \mathrm{Ca}+\mathrm{Mg}, \mathrm{Ca}, \mathrm{Mg}$ [10], [11];

- Spectrophotometric methods provided by Merck-Millipore kits: COD, TOC, N_total, N_NH4, N_NO3, N_NO2, P_total, Cl, SO4, Fe_total, Zn, Pb, Ni [12]-[24].

\section{Statistical Analysis}

The data obtained from the analyses performed on the 27 indicators were tested with t-Test with SPSS software and the values obtained were compared both with the maximum limits allowed by the European and Romanian legislation [27], [28] and with the complete studies on the Danube made in the previous years [29]-[32]. The results obtained are presented in Table 1 below.

Table 1. T-Test Results

\begin{tabular}{ccccc}
\hline \hline Parameter & Minimum & Maximum & Mean & Std. Deviation \\
\hline pH & 7.40 & 8.24 & 7.85 & 0.24 \\
C & 305.00 & 331.00 & 315.53 & 7.89 \\
TDS & 152.00 & 165.00 & 157.27 & 4.01 \\
DO & 4.78 & 6.58 & 5.64 & 0.67 \\
DO_Sat & 60.56 & 80.81 & 69.64 & 7.55 \\
Turbidity & 2.61 & 43.30 & 17.09 & 15.77 \\
TSM & 5.50 & 49.60 & 19.91 & 13.83 \\
M_Alkalinity & 0.53 & 0.82 & 0.66 & 0.12 \\
HCO3 & 32.23 & 50.02 & 39.98 & 7.41 \\
DT & 7.99 & 9.44 & 8.71 & 0.41 \\
D_t & 1.51 & 2.30 & 1.85 & 0.33 \\
D_p & 5.95 & 7.51 & 6.86 & 0.58 \\
Ca & 18.40 & 63.15 & 44.77 & 9.27 \\
Mg & 44.78 & 84.64 & 54.72 & 9.46 \\
COD & 15.60 & 26.80 & 20.80 & 2.98 \\
TOC & 19.50 & 29.20 & 24.32 & 3.65 \\
N_total & 0.30 & 2.20 & 1.54 & 0.51 \\
N_NH4 & 0.20 & 0.42 & 0.30 & 0.09 \\
N_NO3 & 1.30 & 3.90 & 2.08 & 0.81 \\
N_NO2 & 1.30 & 19.50 & 6.58 & 5.51 \\
P_total & 0.06 & 5.92 & 0.63 & 1.51
\end{tabular}




\begin{tabular}{ccccc}
\hline \hline Parameter & Minimum & Maximum & Mean & Std. Deviation \\
\hline $\mathrm{Cl}$ & 26.00 & 47.00 & 34.80 & 6.03 \\
$\mathrm{SO} 4$ & 22.00 & 51.00 & 29.53 & 6.73 \\
Fe_total & 0.01 & 0.51 & 0.16 & 0.18 \\
$\mathrm{Zn}$ & 0.03 & 0.15 & 0.09 & 0.04 \\
$\mathrm{~Pb}$ & 0.01 & 0.25 & 0.09 & 0.08 \\
$\mathrm{Ni}$ & 0.18 & 1.32 & 0.56 & 0.52 \\
\hline
\end{tabular}

The Pearson correlation is presented in Fig. 2. As it may be seen 37 out of 56 correlations have a correlation coefficient of $1 \%$ and the remaining 19 correlations have a correlation coefficient of $5 \%$.

22 of the 37 correlates which have a correlation coefficient of $1 \%$, are positive (TDS-C, DO_Sat-DO, Turbidity-C, Turbidity-TDS, TSM-C, TSM-TDS, TSM-Turbidity, HCO3-M_alcalinity, D_t-M_alcalinity, D_t-HCO3, D_p-DT, $\Sigma \mathrm{Ca}+$ Mg-DT, $\Sigma \mathrm{Ca}+\mathrm{Mg}$-D_p, Cl-C, SO4-Ptotal, Fe_total-N_NH4, Zn-DO, Zn-M_alcalinity, Zn-HCO3, $\mathrm{Zn}-\mathrm{D}_{-} \mathrm{t}, \mathrm{Pb} \_\mathrm{C}, \mathrm{Pb}-\mathrm{TDS}$ ) and 15 are negative (DO-C, DO-TDS, DO_Sat-C, DO_Sat-TDS, Turbidity_DO_Sat,

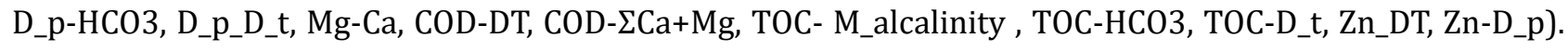
3 out of the 22 positive correlations reached a value of 1.000 , two of these correlations being expected (HCO3-M_alkalinity, $\Sigma \mathrm{Ca}+\mathrm{Mg}-\mathrm{DT}$ ) and one unexpected (Fe_total-N_NH4).

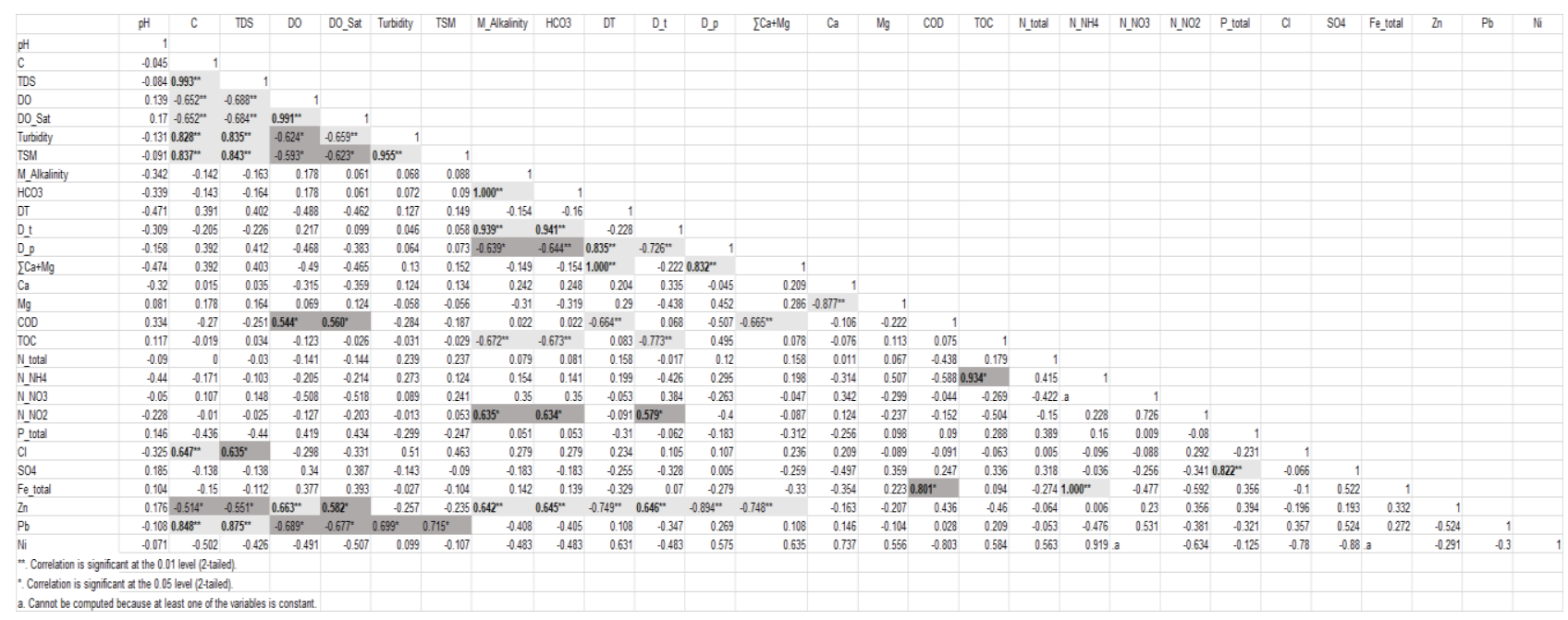

Fig. 2. Pearson correlation results.

11 of 19 correlations with the correlation coefficient of 5\%, are positive (COD-DO, COD-DO_Sat, N_NH4-TOC, N_NO2-M_Alkalinity, N_NO2-HCO3, N_NO2-D_t, N_NH4-TOC, Cl-TDS, Fe_total-COD, Zn-DO_Sat, $\mathrm{Pb}_{-}$Turbidity) the remaining 8 being negative (Turbidity-DO, TSM-DO, TSM-DO_Sat, D_p-M_Alkalinity, Zn-C, Zn-TDS, Pb-DO, Pb-DO_Sat).

BoxPlot representations were made for all the monitored quality parameters, but only those illustrating the influence that the tributaries may have on the Danube River (Fig. 3-6) are presented here.

Thus, analyzing the BoxPlot for C, TDS, TSM and Turbidity (Fig. 3), one could notice that River Prut, one of the most important tributaries of the Danube, brings a significant change to all the indicators referring to the salinity and turbidity of the surface water. From the first sampling point (PD), located upstream, to the last (PD), located downstream, the range of the quality parameters values tends to increase.

The BoxPlot representation for the quality indicators referring to water hardness (Fig. 4) demonstrates that, in the case of DT, there is a wider range of values at the upstream sampling point (PD) for which the median of values is closer to the high values. The median has a decreasing trend from the first sampling point (PD) to the last one (DP). In case of Mg and Ca concentration the trend is increasing from the first to 
the last sampling point and the values of the median for the PD point are closer to the low values. For D_t and D_p the medians have antagonistic values for each sampling point.
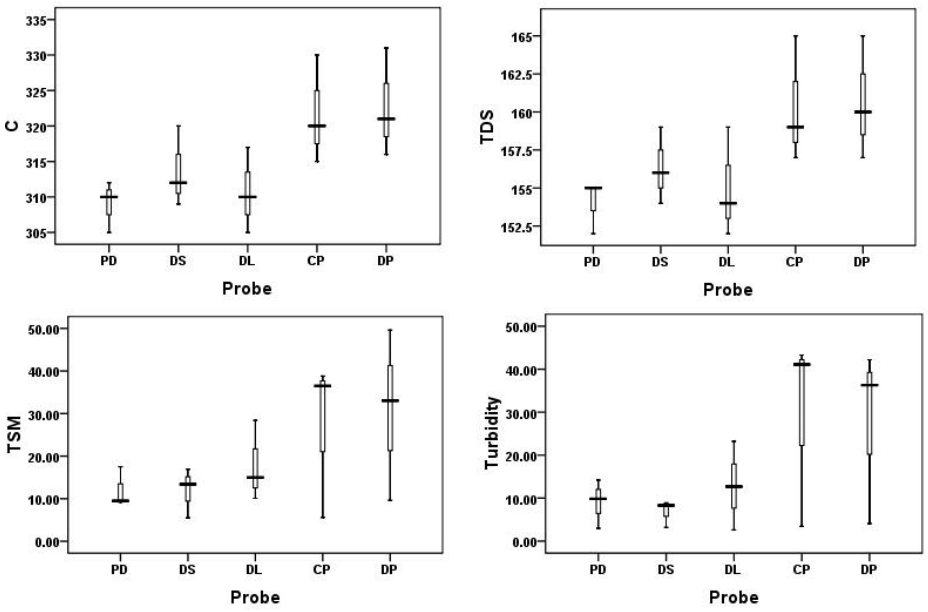

Fig. 3. BoxPlot for C, TDS, TSM and turbidity.
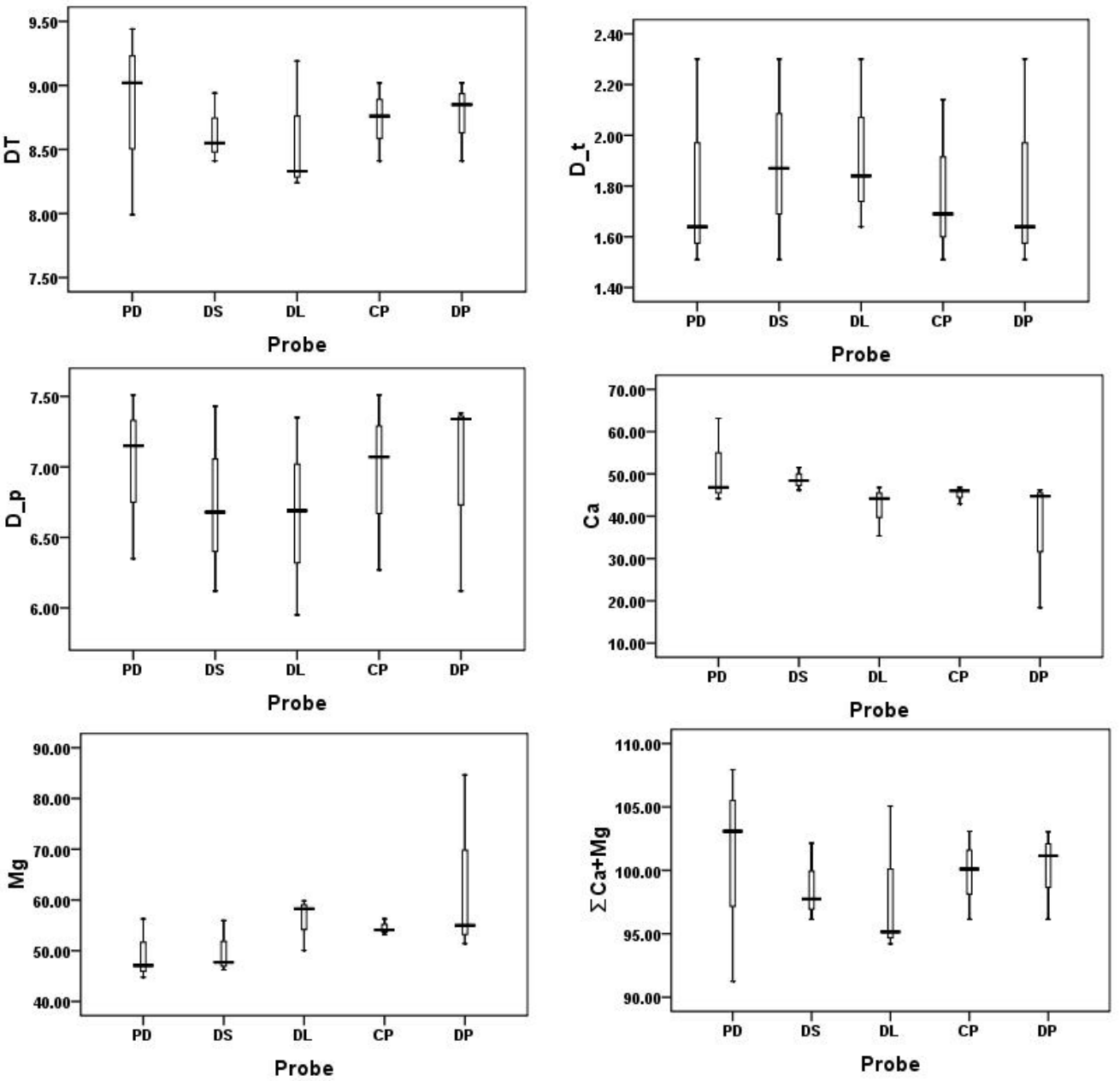

Fig. 4. BoxPlot for DT, D_t, D_p, $\sum \mathrm{Ca}+\mathrm{Mg}, \mathrm{Mg}$, Ca.

Since the $\mathrm{pH}$ did not exceed 8.5 , in any of the samples analyzed, only alkalinity relative to methylorange (M_Alkalinity) was determined and the HCO3 anion concentration was calculated. The BoxPlot 
representation of the values obtained for these two water quality indicators (Fig. 5) showed the fact that only at the DL point, after the Siret confluence with the Danube River, the range of the values is lower than the other sampling points. This could be explained by the influence that River Siret (the Danube's second largest tributary) might have on the quality of the Danube River waters, but also by the Danube River extraordinary ability to self-purify.
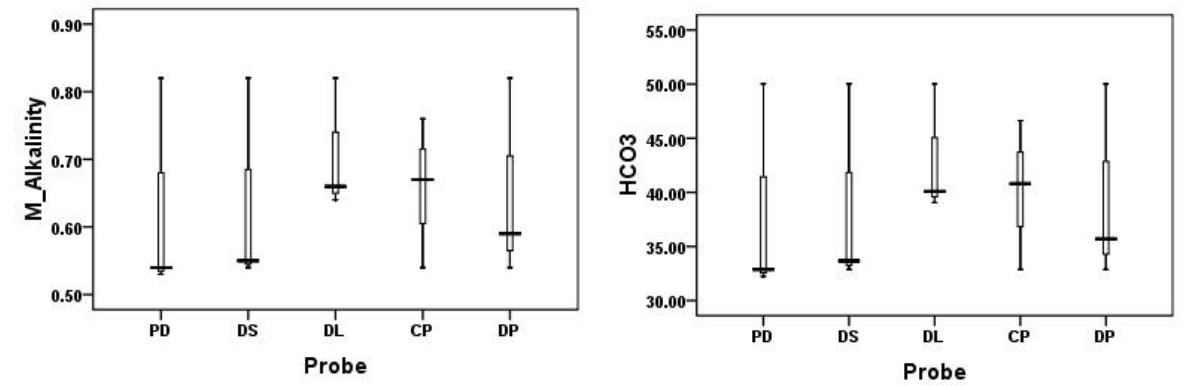

Fig. 5. BoxPlot for M_Alkalinity and HCO3.

The BoxPlot representation of nutrient values (Fig. 6) showed that in the case of P_total there was a pollution event at the DL sampling point. For two consecutive weeks the values of this indicator were higher than the legal limits allowed by the Romanian legislation in force [33]. Knowing the implications of the phenomenon of eutrophication with a high concentration of phosphorus in surface waters [34], [35], we suggest that these quality indicators should be monitored weekly rather than monthly, as they are monitored today. At the same sampling point, DL, N-total has the smallest range of values and N_NO2 the highest. The median of all nutrient values is generally closer to the lower values and the range of values for each indicator decreases as the sampling point approaches the Danube Delta.
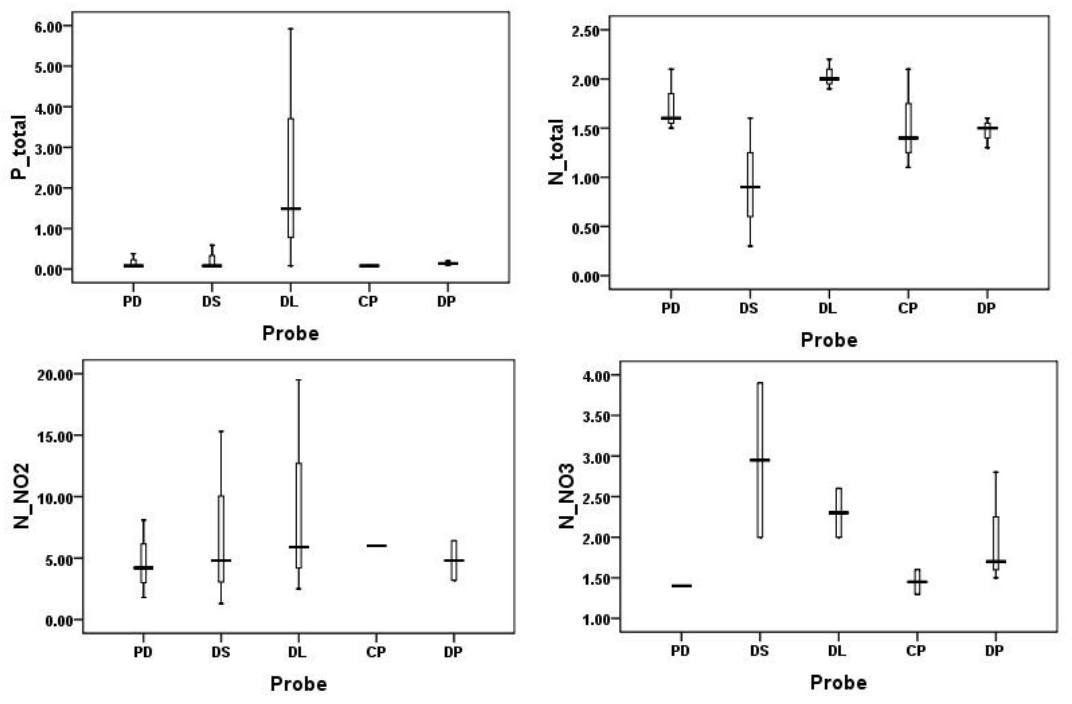

Fig. 6. BoxPlot for nutrients.

\section{Conclusions}

As part of a successful research project at "Dunarea de Jos" University of Galati in June-July 2018, a monitoring of about 30 quality indicators on the Danube River was carried out. The results obtained are the subject of a preliminary statistical analysis meant to establish the most important water quality indicators 
to be monitored and the frequency with which these indicators should be monitored. The monitoring was carried out on a surface water body of approximately $25 \mathrm{~km}$, where the confluences of the Danube River with two of its most important tributaries are also present: the Siret and the Prut Rivers. The results obtained so far have led to the conclusion that the frequency of nutrient monitoring should be changed from monthly to weekly. Thus, the pollution events which negatively affect the aquatic life, the source of pollution identified and the necessary legal measures to be taken could be identified and reported.

\section{Acknowledgements}

This work was supported by the project "Strategy and actions to prepare for national participation in the DANUBIUS-RI" acronym "DANS" financed by the Romanian Ministry of Research and Innovation.

\section{References}

[1] Countries of the Danube River Basin. (2018). International Commission for the Protection of the Danube River.

[2] The Ramsar Convention on Wetlands - Romania - Danube Delta. (2018).

[3] Iticescu, C., Murariu, G., Georgescu, P. L., Burada, A., \& Topa, C, M., (2016). Seasonal variation of the physico-chemical parameters and Water Quality Index (WQI) of Danube water in the transborder Lower Danube area. Rev. De Chimie (Bucharest), 67(9), 1843-1849.

[4] Iticescu, C., Georgescu, P. L., \& Topa, C. M., (2013). Assessing the danube water quality index in the city of Galati, Romania. Carpathian Journal of Earth and Environmental Sciences, 8(4), 155-164.

[5] SR ISO 10523:2009. Water quality standard. Determination of $\mathrm{pH}$.

[6] SR EN 7888:1985. Water quality standard. Determination of conductivity.

[7] SR EN 25813:2000 - Water quality standard. Determination of dissolved oxygen content.

[8] ISO 7027-1:2016, Water quality standard. Determination of turbidity - Part 1: Quantitative methods.

[9] Determination of TSM with lab test method.

[10] ISO 9963-1:1994(en). Water quality — Determination of alkalinity — Part 1: Determination of total and composite alkalinity.

[11] ISO 6059:1984(en). Water quality - Determination of the sum of calcium and magnesium - EDTA titrimetric method.

[12] ISO 6060:1989(en). Water quality - Determination of the chemical oxygen demand.

[13] Spectroquant TOC - Cell Test - instruction for use.

[14] Spectroquant ${ }^{\circledR}$ Azot - Cell Test - instruction for use.

[15] Spectroquant ${ }^{\circledR}$ Amoniu - Cell Test - instruction for use.

[16] Spectroquant ${ }^{\circledR}$ Nitrat - Cell Test - instruction for use.

[17] Spectroquant ${ }^{\circledR}$ Nitrit - Cell Test - instruction for use.

[18] Spectroquant ${ }^{\circledR}$ - Phosphate - Cell Test - instruction for use.

[19] Spectroquant ${ }^{\circledR}$ Chloride - Cell Test - instruction for use.

[20] Spectroquant ${ }^{\circledR}$ Sulphate - Cell Test - instruction for use.

[21] Spectroquant ${ }^{\circledR}$ Iron - Cell Test - instruction for use.

[22] Spectroquant ${ }^{\circledR}$ Zinc - Cell Test - instruction for use.

[23] Spectroquant ${ }^{\circledR}$ Lead - Cell Test - instruction for use.

[24] Spectroquant® Nickel - Cell Test - instruction for use.

[25] ISO 5667-1:2006(en). Water quality - Sampling - Part 1: Guidance on the design of sampling programmes and sampling techniques

[26] ISO 5667-3:2018. Water quality - Sampling - Part 3: Preservation and handling of water sample. 
[27] Water Framework Directive 2000/60/EC of European Parliament and European Commission. European Community Official Journal.

[28] Romanian Law no. 310/2004 which modified the water Romanian Law no. 107/1996.

[29] Popa, P., Murariu, G., Timofti, M., \& Georgescu, L. P. (2018). Multivariate statistical analyses of water quality of Danube River at Galati, Romania. Environmental Engineering and Management Journal, 17(5), 491-510.

[30] Topa, M., C., Timofti, M., Burada, A., Iticescu, C., Georgescu, L. P. (2015). Danube water quality during and after flood near an urban agglomeration, Journal of Environmental Protection and Ecology, 16(4), 1255-1261.

[31] Iticescu, C., Georgescu, L., P., Topa, C., Murariu, G. (2014). Monitoring the Danube water quality near the Galati city. Journal of Environmental Protection and Ecology (JEPE), 15(1), 30-38.

[32] Pintilie, V., Ene, A., Georgescu, L. P., Moraru, L., \& Iticescu, C. (2016). Measurements of gross alpha and beta activity in rinking water from Galati region. Romania, Romanian Reports in Physics, 68(3), 1208-1220.

[33] European Community (EC). Council directive of 16 June 1975 concerning the quality of surface water intended for the abstraction of drinking water in the Member States. 75/440/EEC. Off. $J$ Eur/ Communities (EC).

[34] Poikane, S., Ritterbusch, D., Argillier, C., Białokoz, W., Blabolil, P., Breine, J., Jaarsma, N. G., Krause, T., Kubečka, J., Lauridsen, T. L., Nõges, P., Peirson, G., \& Virbickas, T. (2017). Response of fish communities to multiple pressures: Development of a total anthropogenic pressure intensity index, Science of the Total Environment, 586, 502-511.

[35] Jarvie, H. P., Smith, D. R., Norton, L. R., Edwards, F. K., Bowes, M. J., King, S. M., Scarlett, P., Davies, S., Dils, R., M., \& Bachiller-Jareno, N., (2018). Phosphorus and nitrogen limitation and impairment of headwater streams relative to rivers in Great Britain: A national perspective on eutrophication. Science of the Total Environment, 621, 849-862.

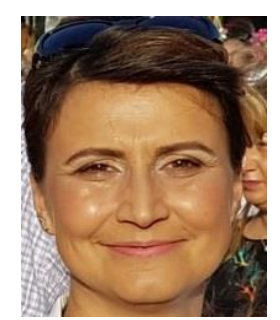

Mihaela Timofti was born in Romania on 14 July 1973. From October 2013 until now, she is lecturer at the Faculty of Sciences and Environment, "Dunărea de Jos" University of Galati, Romania. She got the doctoral degree in industrial engineering at "Dunarea de Jos" University of Galati, Romania, the PhD thesis entitled "Assessment of surfaces with the assistance of statistical Methods"; and the master's degree in "Environmental management and monitoring" at the Faculty of Sciences and Environment, "Dunarea de Jos" University of Galati; and the specialization degree in computer science at the Department of Continuous Training and Technological Transfer, "Dunarea de Jos" University of Galati.

Timofti has been a member of the Chemistry Society of Romania since 2003, of the Romanian Environmental Association - 1998 (ARM) since 2010 and a Senior Member of HKCBEES since 2018. 